Rabaska

Revue d'ethnologie de l'Amérique française

\title{
Le Culte à sainte Anne en Acadie : étude ethnohistorique
}

Volume 10, 2012

URI : https://id.erudit.org/iderudit/1013548ar

DOI : https://doi.org/10.7202/1013548ar

Aller au sommaire du numéro

Éditeur(s)

Société québécoise d'ethnologie

ISSN

1703-7433 (imprimé)

1916-7350 (numérique)

Découvrir la revue

Citer ce document

(2012). Le Culte à sainte Anne en Acadie : étude ethnohistorique. Rabaska, 10, 177-182. https://doi.org/10.7202/1013548ar d'utilisation que vous pouvez consulter en ligne.

https://apropos.erudit.org/fr/usagers/politique-dutilisation/ 


\section{Place publique}

Points de vue / livre

\section{Le Culte à sainte Anne en Acadie : étude ethnohistorique}

Pour rendre compte du parcours multidisciplinaire de Denise Lamontagne, qui se déploie dans l'étude ethnohistorique qu'elle consacre à la dévotion à sainte Anne en Acadie, quatre invités commentent l'étude récente de ce professeur d'histoire comparée des religions à l'Université de Moncton. D'abord le professeur Georges Provost, maître de conférences à l'Université de Rennes 2, spécialiste de l'histoire religieuse et culturelle des XVII ${ }^{\mathrm{e}}$ et XVIII ${ }^{\mathrm{e}}$ siècles et des pèlerinages en domaine breton notamment ; Guy Laperrière, professeur retraité de l'Université de Sherbrooke, spécialiste de l'histoire religieuse comparée du Québec et de la France aux XIX ${ }^{\mathrm{e}}$ et $\mathrm{XX}^{\mathrm{e}}$ siècles, des congrégations religieuses en particulier ; Micheline Laliberté, professeur d'histoire au département des Sciences humaines de l'Université SainteAnne, qui a examiné le phénomène de la religion populaire dans la France des $\mathrm{XV}^{\mathrm{e}}$ et $\mathrm{XVI}^{\mathrm{e}}$ siècles et s'intéresse à l'histoire des mentalités en milieu acadien ; et Anne Doran, professeur associé au département des Sciences humaines de l'Université du Québec à Chicoutimi et maintenant rattachée à l'Institut de pastorale des dominicains à Montréal, qui a scruté la place de la dévotion à sainte Anne dans la spiritualité amérindienne. Leurs points de vue contribuent à éclairer quelques-uns des thèmes de cet ouvrage aux multiples facettes.

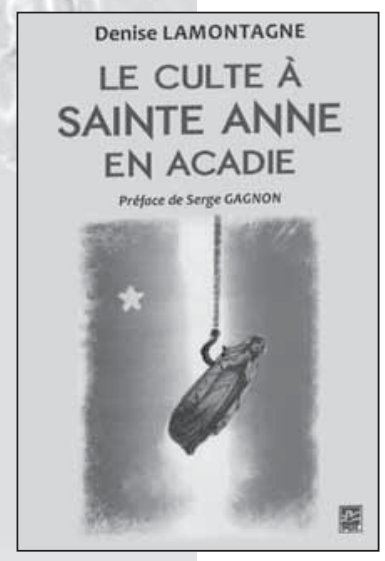

Denise Lamontagne

Le Culte à sainte Anne en Acadie : étude ethnohistorique

Les Presses de l'Université Laval « Les Archives de folklore» 29

2011, xx-361 p. ill.

ISBN 978-2-7637-9323-8 